\title{
UN SEGMENT DE LIMES REDESCOPERIT: LUNCAVIȚA, JUD. TULCEA
}

Ovidiu Țentea

\section{Rezumat}

Lucrarea evaluează descoperirile din cinci situri databile în perioada Principatului într-un areal restrâns din vecinătatea a două fortificații învecinate de pe cursul inferior al Dunării. Acest demers este o continuare a unui studiu recent, prin care readuceam în discuție fortificația romană de la Luncavița, Dealul Milan. Pe lângă noile elemente care detaliază fortificația de pe Dealul Milan, studiul integrează observațiile referitoare la fortificația de la Rachelu și din alte 3 situri din proximitate. Subliniem amplasarea celor două fortificații și a unui sit (cel mai probabil, necropolă) la limita terasei înalte a Dunării, o caracteristică a majorității fortificaților romane de pe frontiera dunăreană. Imaginea oferită de dispunerea celor cinci situri ne oferă o perspectivă mult mai relevantă a dimensiunii ocupării teritoriului în perioada Principatului și a modului în care funcționau instalațiile militare și rețelele rutiere.

\section{Abstract (A rediscovered section of the limes: Luncaviţa, Tulcea County)}

This paper studies the discoveries made in five archaeological sites from the Principate Age situated in a relatively small area in the vicinity of 2 neighboring forts situated on the Lower Danube. This is a continuation of a previous study which brought back to attention the roman fort from Luncavița, Dealul Milan. In addition to the new found information that gives further insight into the fort on the Dealul Milan, this study integrates the observations regarding the Rachelu fort (quadriburgium) and three other sites nearby. We emphasize the location of the two forts and an archaeological site (most probably, a necropolis) on the higher terrace of the Danube. This is a feature of most of the Roman forts situated on the Danubian frontier. The arrangement of these five sites gives us a much more relevant perspective over the size of the territory's occupation during the Principate and the way in which the military installations and road networks functioned.

Cuvinte cheie: frontiera romană, Principat, Dunăre, fortificații romane, situri arheologice

Key words: Roman frontiers, Principate, Danube, Roman forts, archaeological sites

\section{INTRODUCERE}

În urmă cu trei ani am publicat un articol care reintroducea în discuție o fortificație "dispărută"1 din sistemul defensiv roman de pe cursul inferior al Dunării. Este vorba despre fortificația romană de la Luncavița, amplasată între cele de la Dinogetia și Noviodunum, segment care în lucrările de sinteză referitoare la frontiera epoca Principatului, părea de două ori mai lung decât distanțele la care au fost amplasate celelalte fortificații romane de pe cursul inferior al Dunării.

\footnotetext{
${ }^{1}$ Țentea $2015,269-275$.
} 


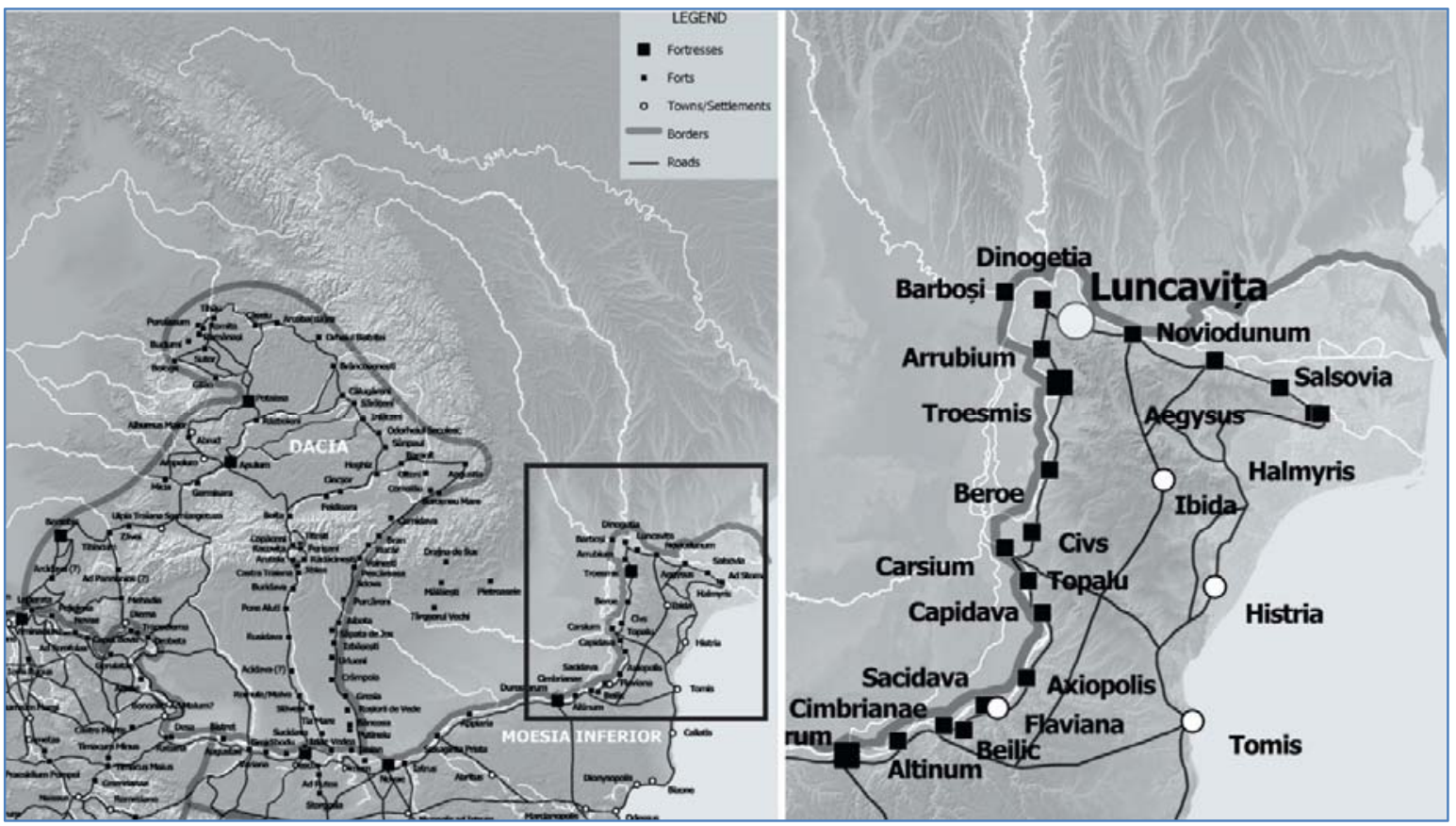

Figura 1. Harta provinciile romane din zona Dunării de Jos în epoca Principatului (stânga) şi detaliu (dreapta).

\section{DEALUL MiLAN}

La Luncavița, pe Dealul Milan, un platou de natură stâncoasă având cota 48 metri $^{2}$, a fost semnalată o fortificație cu dimensiuni de aproximativ $225 \times 75 \mathrm{~m}^{3}$. Prima semnalare apare în manuscrisele lui Gr. Tocilescu, date care au fost folosite de cele mai multe ori în lucrările ulterioare. Planul a fost realizat de inginerul topograf P. Polonic, în ultimii ani ai secolului XIX (Figura 2), delegat de Tocilescu, la acea vreme directorul Muzeului Naţional de Antichităţi, să efectueze cercetări și măsurători de suprafaţă în diferite zone ale Dobrogei ${ }^{4}$.

Despre acest sit s-au făcut ulterior doar referiri lacunare în lucrări de sinteză privind frontiera romană $\breve{s}^{5}$ în voci din dicţionare sau în scurte menționări ale unor cercetări arheologice din arealul respectiv, dar privitoare la alte epoci istorice sau descoperiri întâmplătoare ${ }^{6}$.

Cercetarea detaliată a ortofotoplanurilor (Figura 3) și a hărților au indicat o situație mult mai complicată decât cea cunoscută din publicații. Am aprofundat această temă prin examinarea datelor satelitare, coroborate cu aeriene oblice realizate în anul 2008, cu scanări 3D parțiale ale sitului și cu o serie de

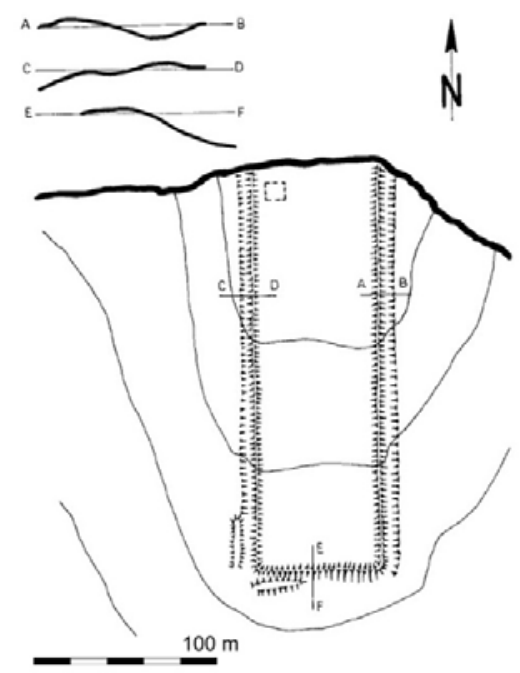

Figura 2. Luncavița, Milan, planul fortificației (Tocilescu 1898, 100-101).

\footnotetext{
${ }^{2}$ Cota fluviului, în aval de Galaţi, este de 2 m (referinţă Marea Neagră).

${ }^{3}$ Barnea 1996, 334; Zahariade, Gudea 1997, 81 no. 49; Gudea 2005, 457. Acest plan oferă delimitarea fortificației pe trei laturi, cea nordică părând distrusă de eroziune, cf. Tocilescu 1898.

${ }^{4}$ Aceste date au fost incluse cel mai probabil în Marele dicţionar geografic al României, Dealul Milan - Lahovari et al. $1901,339$.

${ }^{5}$ Zahariade, Gudea 1997, 81, no. 49; Gudea 2005, 457-458, no. 49. Semnalările nu au adus date noi față de planurile lui Pamfil Polonic.

${ }^{6}$ Comșa 1952, 413-416; Poenaru-Bordea 1996, 86-87, no. 140-141. Vezi și nota 3.
} 
recunoașteri la fața locului. Rezultatele acestor cercetări au avut ca rezultat restituirea parțială a planului fortificației romane târzii de la Luncavița, Dealul Milan ${ }^{7}$, dintre care voi face o scurtă prezentare în cele ce urmează.
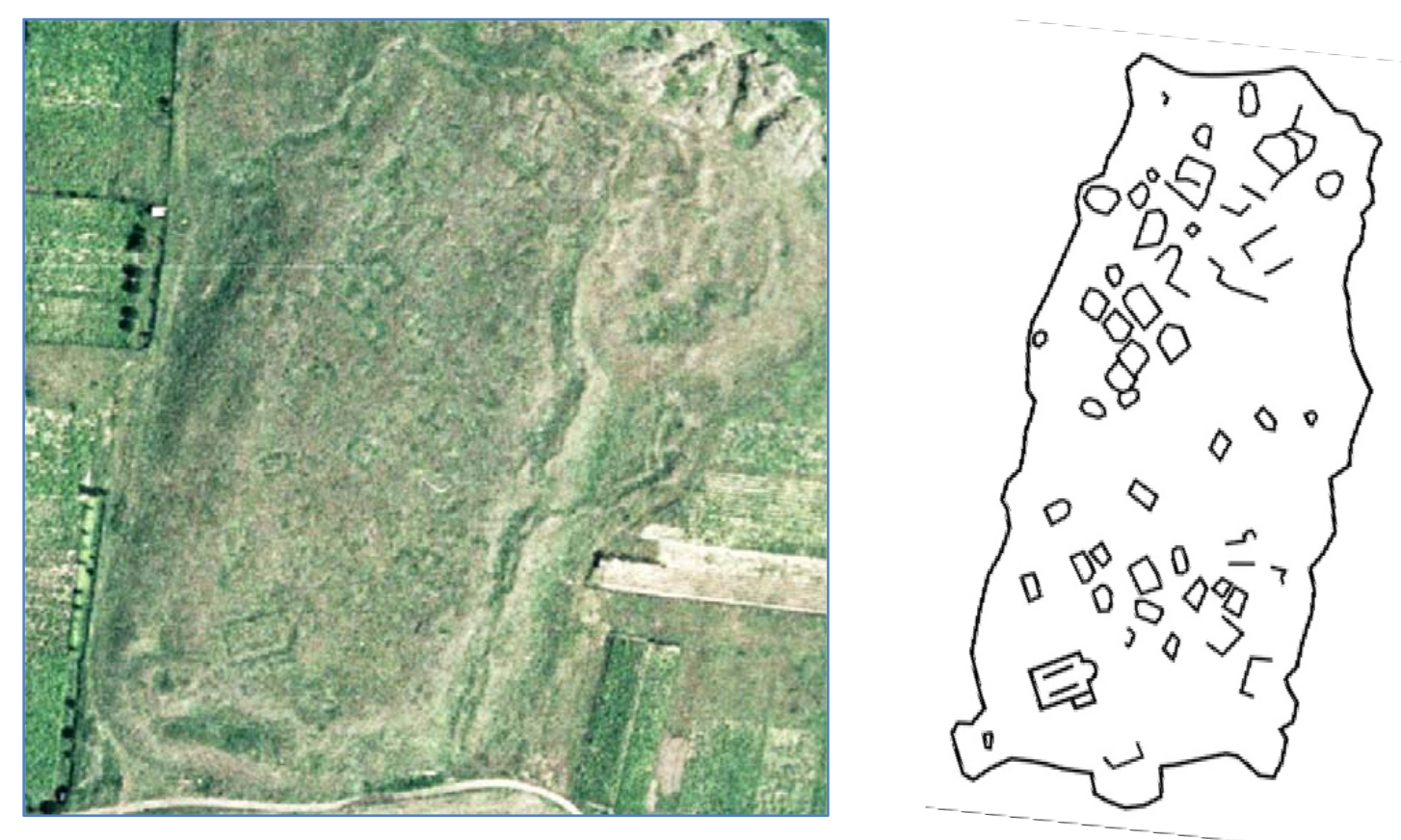

Figura 3. Luncavița, Milan, ortofotografie (stânga, rezoluţie 0,5 m) şi interpretarea imaginii, schiţă (dreapta), ambele după Țentea 2015, 272, fig. 6 a.

Contururile zidurilor de incintă și ale unor clădiri din interior pot fi observate cu acuratețe în negativele șanţurilor de scoatere a zidurilor ${ }^{8}$. Fără a putea realiza un plan detaliat foarte precis, am reuşit să redăm parțial planul fortificației și al unor clădiri din interior (Figura 3). Corelarea abaterilor nu influențează major planimetria întregii fortificații. Şanțurile de scoatere a zidurilor au fost săpate de-a lungul acestora, urmărindu-se una dintre fețele zidurilor. Cantitatea de pământ aruncat în urma acestei intervenții nu este prea mare, fapt care nu a perturbat prea mult observațiile noastre. Nu același lucru se poate spune însă despre degajarea zidurilor de incintă. Aici contururile zidurilor se văd cu dificultate şi ne referim în special la turnuri de curtină și la porți. După cum aminteam, aceste intervenții au fost realizate înainte de începutul secolului XX. Incinta are o formă patrulateră, având lungimea aproape dublă față de lățime (Figura 4). Latura lungă, orientată Nord-Sud are o lungime de $237 \mathrm{~m}$, iar cea scurtă între $87 \mathrm{~m}$ (latura nordică) și 93 m (latura sudică). Se pot observa turnurile în formă semicirculară (trapezoidală?) pe laturile de Est, Sud și Vest și pe colțuri. Cel mai bine se poate observa turnul din colțul sud-vestic, porțiune în care pe planul său, Polonic marcase două scurte porțiuni distincte de val către exterior, fără a trasa conturul unui turn. Pe laturile lungi se pot observa unele mici ondulări care pot proveni de la turnuri de curtină sau porți, însă acestea nu pot fi amplasate cu precizie. Analogii au fost identificate în principal pe baza dimensiunilor și a formei fortificației, luându-se în considerare și numărul sau forma turnurilor?

\footnotetext{
7 Țentea 2015, 269-275.

${ }^{8}$ Lahovari emitea ipoteza existenței unei fortificații romane, notând și faptul că în urma săpăturilor efectuate (" $n u$ în acest scop [...] pentru a se scoate piatră pentru case") nu a fost descoperită nicio inscripție, fapt care 1-a condus la concluzia că mai probabil în acel loc ar fi fost o fortificație turcească (Lahovari et al. 1901, 339).

${ }^{9}$ Dinogetia (Barnea 1986, fig. 3), Troesmis cetatea de vest (Tocilescu 1882, 105), Salsovia (Haynes et al. 2007, 135, fig. 3).
} 


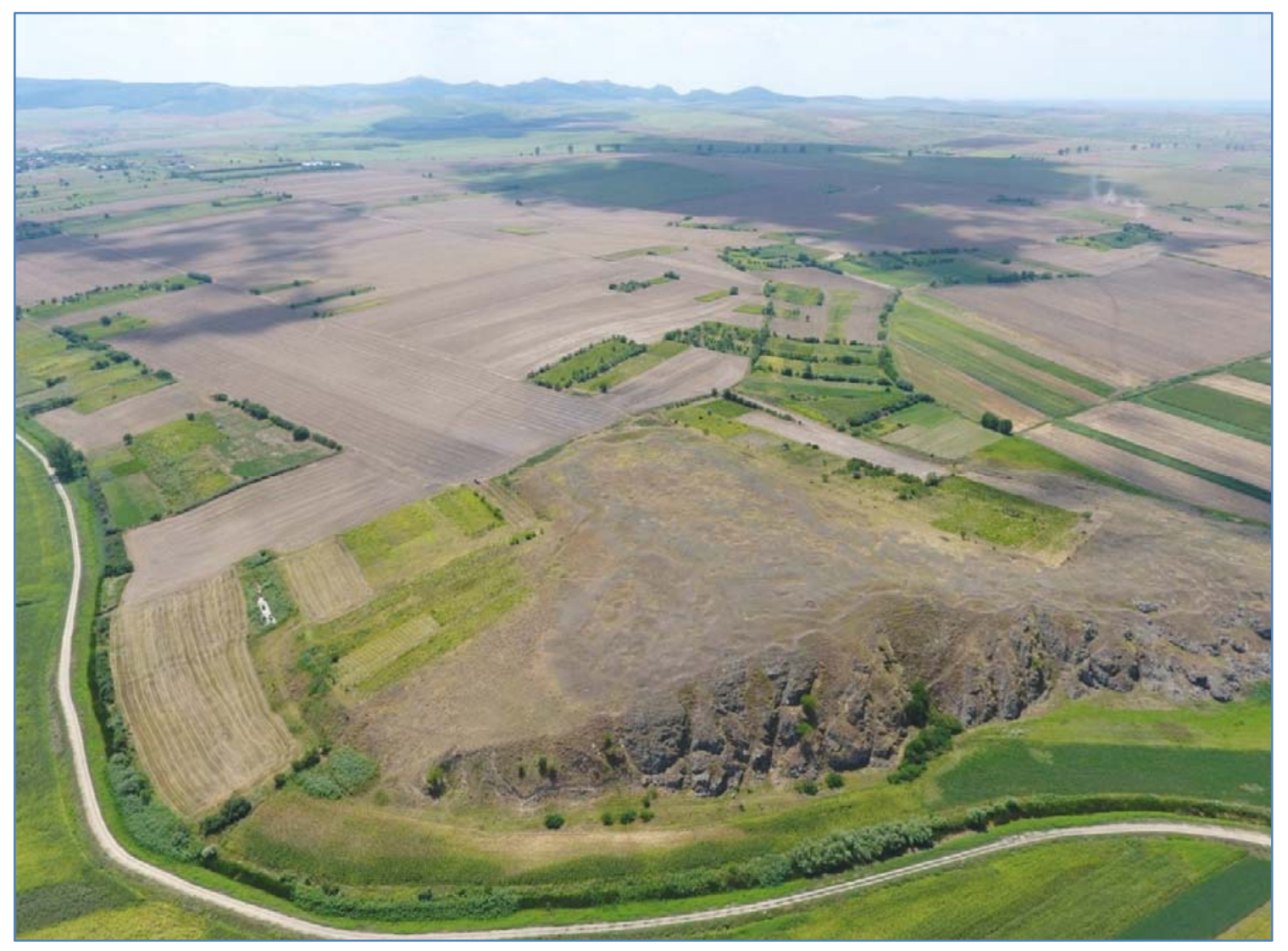

Figura 4. Fotografie aeriană oblică, vedere spre sud (Dan Costea 2018).

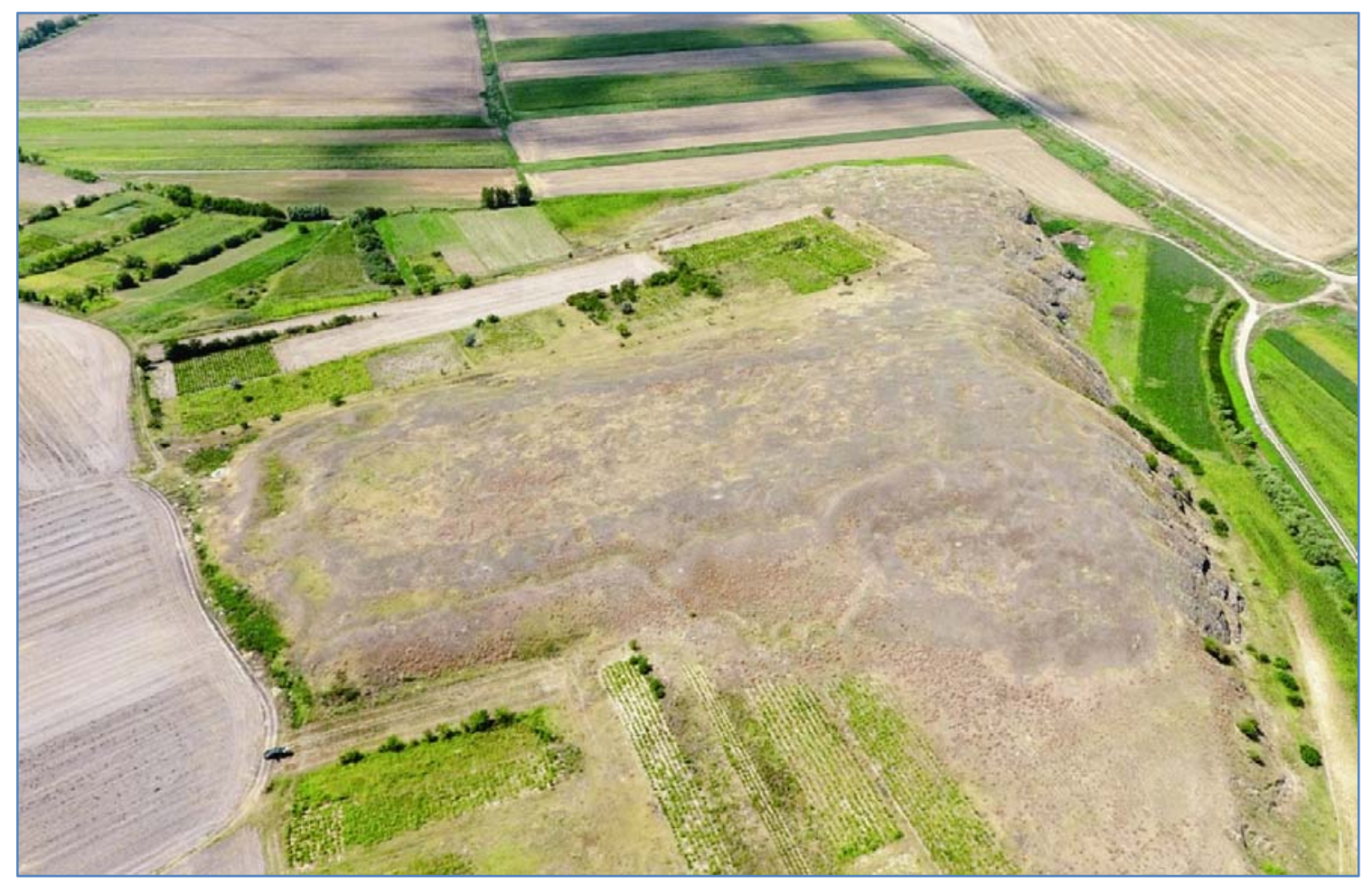

Figura 5. Fotografie aeriană oblică, vedere spre vest (Dan Costea 2018). 


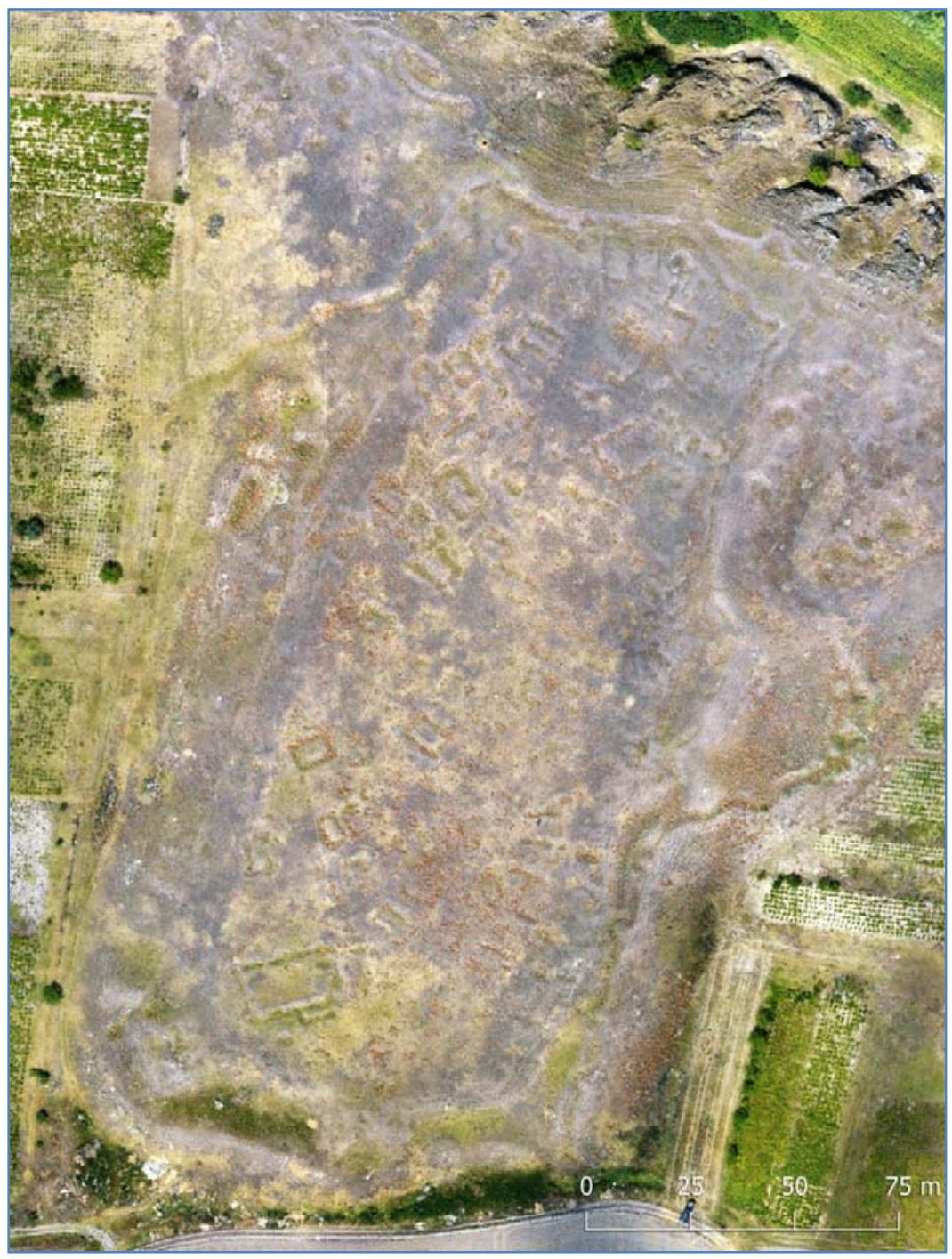

Figura 6. Ortofografie de mare rezoluție (Dan Costea 2018).

În interiorul fortificației se pot observa numeroase amprente delimitate de șanţuri de extragere a pietrei, care provin de la clădiri care au aparținut ultimei faze de locuire în interiorul fortificației. Unele au forme neregulate, ovoidale, dar cele mai multe sunt patrulatere ${ }^{10}$.

Dintre acestea se distinge o clădire dreptunghiulară amplasată în zona sud-vestică a fortificației. Aceasta poate fi identificată cu o basilica cu un naos dreptunghiular, format probabil dintr-o singură navă, care împreună cu absida altarului indică lungimea totală a edificiului (măsurată pe axul orientat Est-Vest) de 19 m. Lățimea edificiului este de $11 \mathrm{~m}$. Pe latura vestică se distinge o curbură destul de accentuată, care nu poate fi decât o absidă. În apropierea colțului sud-estic, adosată laturii sudice, poate fi observată o încăpere dreptunghiulară (baptisterium? vezi Figurile 7-8). Alte detalii relevante pentru reconstituirea compartimentării interne a clădirii nu pot fi identificate ${ }^{11}$.

$\mathrm{Nu}$ se cunosc date referitoare la săpături arheologice pe teritoriul fortificații sau alte informații suplimentare. $\mathrm{Nu}$ sunt cunoscute mențiuni ale vreunei trupe sau indicii asupra numelui antic al cetății. La data la care readuceam în discuție această fortificație, afirmam că este foarte probabil ca fortificația de pe Dealul Milan să fi funcționat pe durata secolelor II-III p.Chr. întrucât în zonele învecinate au fost

\footnotetext{
${ }^{10}$ Prin analogie cu situația binecunoscută de la Capidava, este vorba despre o așezare fortificată de bordeie, care suprapune structurile interne ale fortificaței romano-bizantine din secolele V-VII p. Chr. - Florescu 1958, 138-152; Florescu 2004
}

${ }^{11}$ Țentea 2015, 273-274, fig. 7-8. 
documentate artefacte databile în perioada Principatului. Asupra acestor informații vom reveni în cele ce urmează.

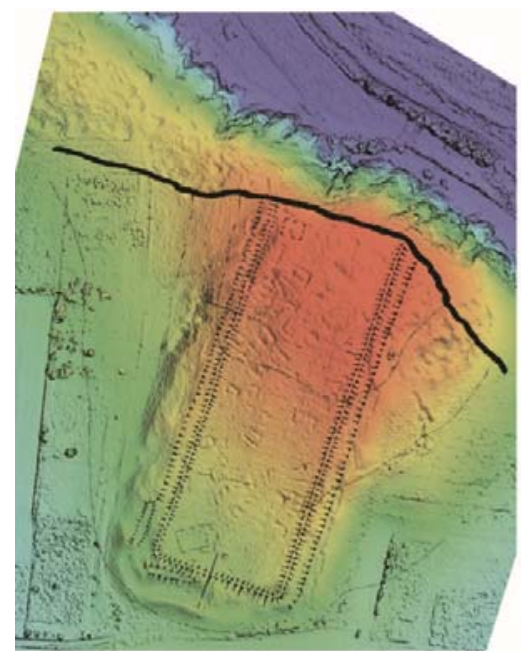

8 s $x=$

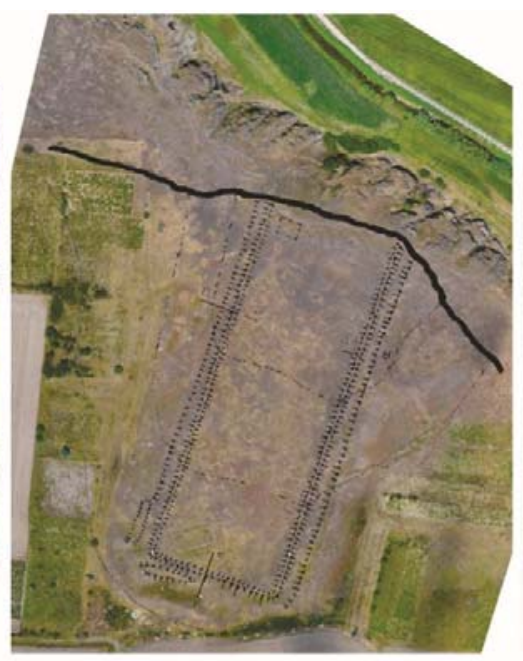

$\therefore$ : 50

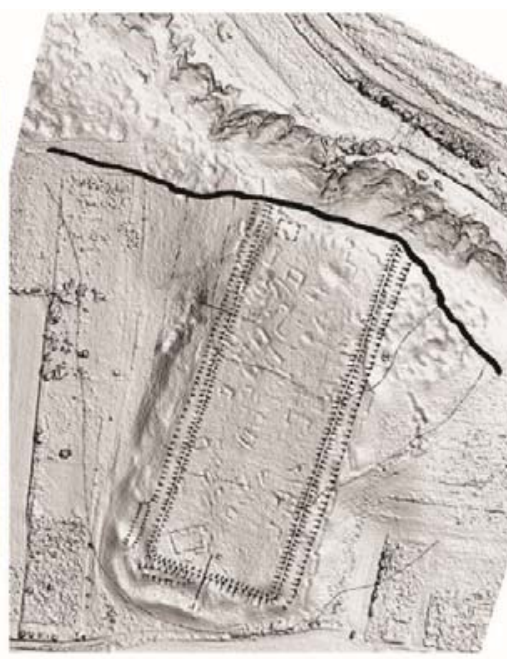

- 8 s $5 \mathrm{~m}$

Figura 7. Planul publicat de Tocilescu $(1989,100-101)$ pentru fortificaţia de la Luncaviţa, suprapus peste modelul digital al terenului (stânga), ortofotografie (centru) şi vederea de tip hillshade a modelului digital (evidenţierea pantelor, dreapta).

Datele acestui studiu au fost reluate în cadrul Programului Naţional LIMES, în cursul procesului de monitorizare a fortificațiilor de pe sectorul sudic al frontierei romane din România. În campaniile din anii 2018 și 2019 am realizat mai multe recunoașteri pe teren și două serii de zboruri cu drona, care s-au materializat cu completarea documentației cartografice a Dealului Milan, dar și a fortificației de la Rachelu, situată, de asemenea, pe teritoriul comunei Luncavița. Pentru o mai bună înțelegere a detaliilor sistemului defensiv roman și a delimitării corespunzătoare a așezărilor și a instalațiilor militare din acestă zonă, investigația a fost extinsă la un areal cât mai larg posibil.

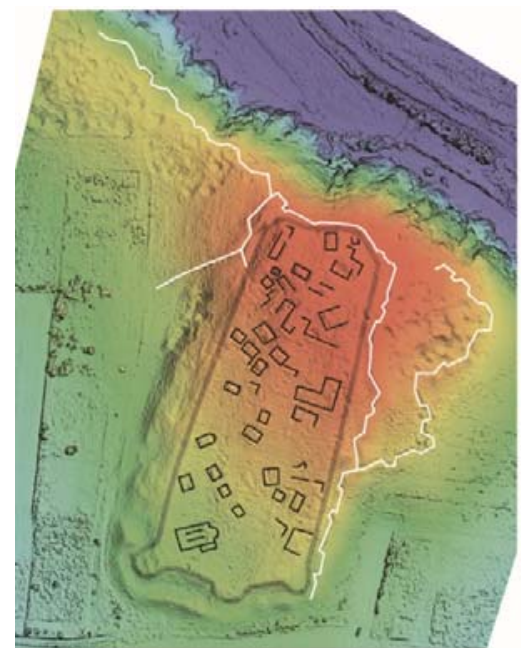

$2505 m$

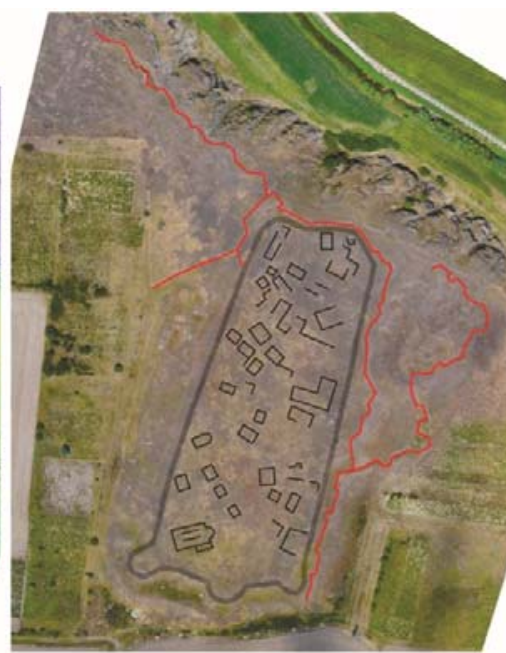

- $25 \quad 5075$

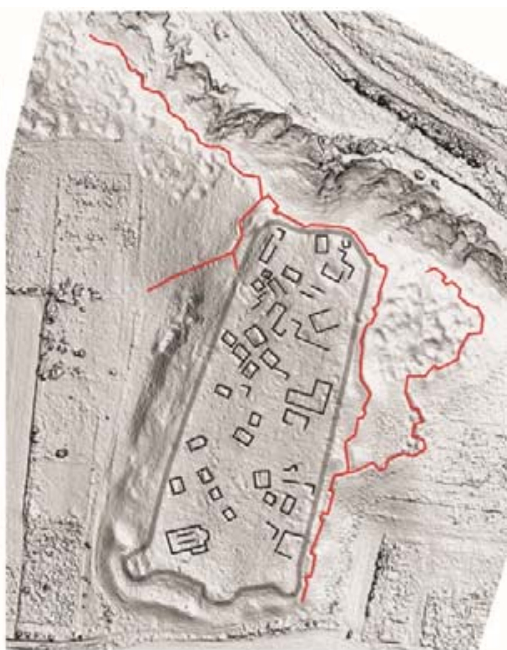

$\therefore \% 2 \mathrm{~m}$

Figura 8. Interpretarea documentaţiei pentru construcţiile de la interiorul fortificaţiei (negru) şi a sistemelor de tranşee moderne (alb, respectiv roşu), pe acelaşi set de imagini ca la Figura 7. 
Acest studiu cuprinde informații rezultate în urma investigațiilor proprii, care au fost coroborate cu informațiile și datele comunicate cu amabilitate de colegii care au efectuat anterior periegheze și săpături arheologice pe teritoriul comunei Luncavița ${ }^{12}$.

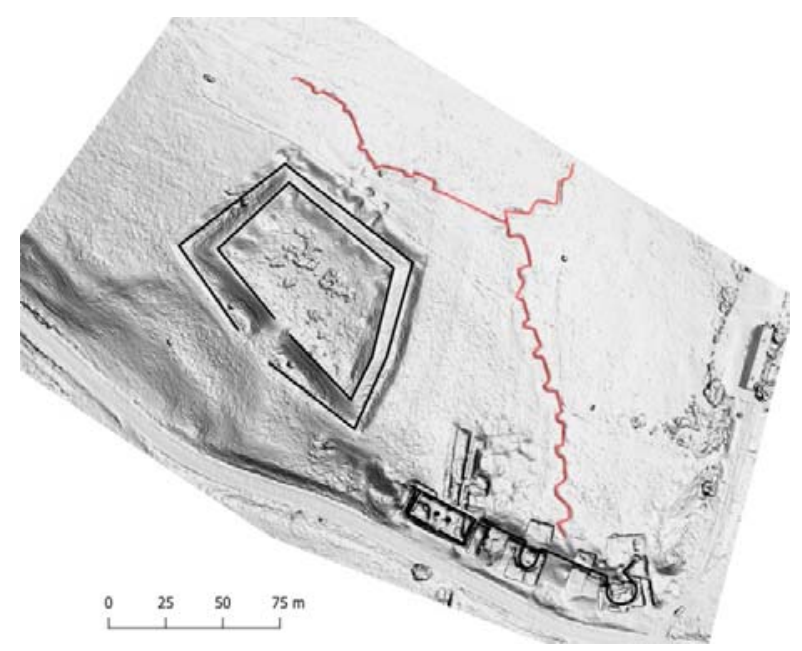

Figura 9. Schiţă parţială a sitului arheologic de la Noviodunum, cu marcarea tranşeelor din Primul Război Mondial (roşu). În stânga - tabia otomană; în dreapta jos - turnuri de epocă romană târzie.
Planul fortificatiei de pe Dealul Milan a fost corectat ca urmare a realizării unor modele efectuate la o rezoluție mai bună $\breve{1}^{13}$, respectiv prin procesarea și analizarea mai detaliată a acestora. Ca urmare, am putut obține câteva detalii suplimentare ale planimetriei interne a fortificației de pe Dealul Milan, precum și observaţii ale traseului incintelor printr-o mai bună corelare cu planul întocmit de Polonic (Figura 7). În urma suprapunerii acestor date, am putut separa cu claritate anumite șanțuri, care în unele porțiuni, conțin elemente de regularitate şi structuri asemănătoare unor tranşee din perioada modernă (Figura 8). Tranşee similare au putut fi identificate şi pe alte situri romane din Dobrogea de nord, precum Novidunum (Figura 9) sau Salsovia (Figura 10). Acestea reflectă activitățile de pe linia frontului desfășurate în cursul Primului Război Mondial. Aceste tranșee au afectat parțial colțul Nord-Vestic și latura nordică a

fortificației antice de pe Dealul Milan. În acestă porțiune a platoului, situată în proximitatea pantei accentuate și stâncoase a dealului, se observă o grupare de adâncituri numeroase cu forme rotunjite care nu au fost semnalate în interiorul fortificației antice. Așa cum s-a putut observa și din notițele lui G.I. Lahovari cea mai mare cantitate de piatră fusese extrasă anterior de către localnici ${ }^{14}$. Aceleași situații au fost înregistrate şi în cursul cercetărilor de la Salsovia ${ }^{15}$, atât ca practică a localnicilor de a demonta zidurile și de a scoate piatra din fundațiile acestora, cât și ca utilizare a fortificației antice ca punct defensiv, în cadrul operațiunilor din cel de-al Doilea Război Mondial (?).

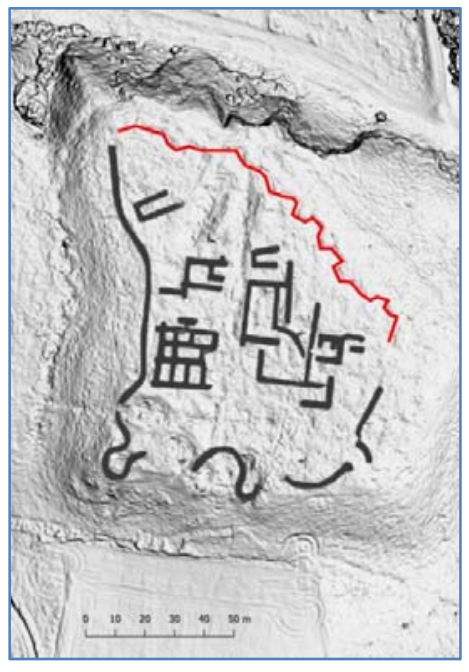

Figura 10. Schiță a sitului arheologic Salsovia cu marcarea tranșeelor moderne (după Topoleanu, Bogdan, Haynes 2012, 110 fig. 20). Cu negru interpretarea urmelor de construcţii antice; $c u$ roşu - tranşee moderne.

\footnotetext{
12 Date regăsite în Studiu istoric şi arheologic comuna Luncavița, capitol al Planului de Urbanism General al comunei - Micu et al. 2012.

${ }^{13}$ Datele au fost colectate și prelucrate primar de către Daniel Costea.

14 Vezi nota 8.

15 Topoleanu, Bogda, Haynes 2012, 107, notele 61, 62.
} 
Așezarea civilă de la Luncaviţa este situată la Sud de fortificație, după cum o indică materialul ceramic vizibil din abundență în urma efectuării lucrărilor agricole.

\section{FORTIFICATTIA DE TIP QUADRIBURGIUM DE LA RACHELU}

Fortificația de tip quadriburgium de la Rachelu a fost amplasată pe un promontoriu stâncos, situat la marginea zonei inundabile a Dunării (Figura 11), în marginea satului. În prezent fortificația este acoperită în mare parte de grădina unei case. În anul 1991 au fost efectuate săpături de salvare care au dus la identificarea turnului circular de Nord-Est, construit din blocuri de piatră legate cu mortar ${ }^{16}$. De pe cele două fortificații era asigurată vizibilitatea atât între ele (Figura 17), cât și mai departe către Dinogetia, respectiv către Noviodunum.

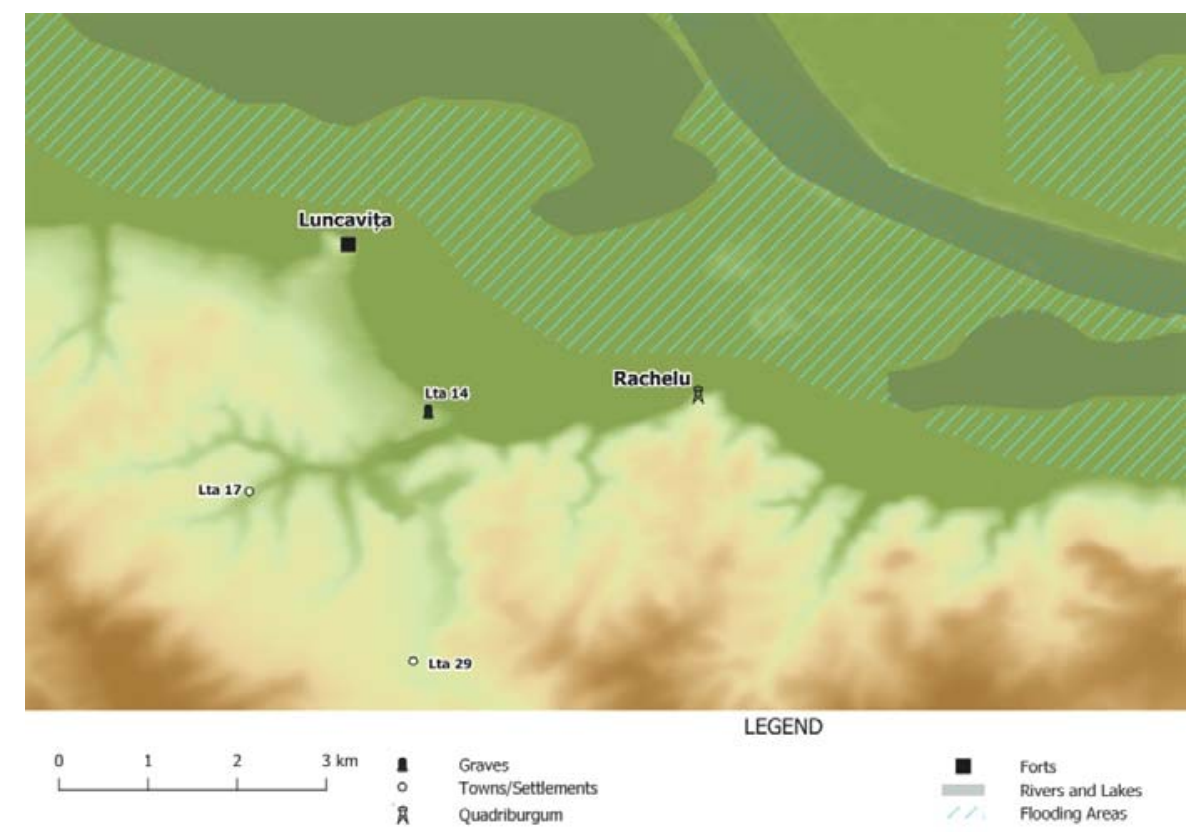

Figura 11. Siturile romane din zona Luncavița - model elevaţie (SRTM).

\section{OCUPAREA ZONEI LUNCAVIȚA ÎN EPOCA PRINCIPATULUI}

Ocuparea zonei Luncavița în epoca Principatului este documentată prin descoperiri de ceramică, dintre care cele mai importante sunt trei amfore, din care una se află în colecția ICEM și două în cea a școlii generale din Luncavița. Acestea provin din situl, denumit convențional "Lta 14" (Figurile 11-12). Acesta este situat în zona de nord-est a satului Luncavița, nu departe de fosta zonă de bălți a Dunării, fiind identificat în anul 2003, în timpul amenajării unei fundații de locuință.

\footnotetext{
${ }^{16}$ Cercetările arheologice au fost efectuate de Mihai Zahariade și Gabriel Jugănaru - Zahariade 1999 a, 202, Băjenaru 2010, 130. Dimensiunile sale (45 x 45 metri) au fost preluate pe baza informațiilor furnizate de P. Polonic. Recunoașterea de teren din aprilie 2019 am făcut-o împreună cu Alexandru Rațiu. Fotografiile din dronă au fost efectuate de Daniel Costea.

Nicolae Gudea a localizat greșit aceasta fortificație de tip quadriburgium de la Rachelu în locul celei de pe Dealul Milan (Gudea 2005, 457-458, no. 49).
} 
Dintre descoperiri au fost amintite două amfore, care ar fi putut aparține unui mormânt databil în secolul al II-lea p.Chr. Există indicii că din inventarul complexului funerar mai făceau parte cel puțin câteva brățări de sticlă ${ }^{17}$.

O amfora, aproape completă, a fost publicată și face parte din colecția ICEM Tulcea, (Figura 12/1) ${ }^{18}$. Amfora are pastă bej, în compoziţie având mică şi particule negre şi maronii (H - 68,4; Dg - 6,8; Dm - 22; $\mathrm{Db}-7,2)$.

Două amfore au fost descoperite în același loc și se păstrează în colecția Școlii Generale din Luncavița (Figura 12/2, 3). Acestea au aceleași caracteristici cu cea publicată de către colegul Dorel Paraschiv, dimensiunile și unele caracteristici fiind ușor diferite, după cum vor fi prezentate în cele ce urmează. Amforele nu sunt întregi, motiv pentru care nu se pot întregistra dimensiunile pentru toți parametrii. Prima are o înălţime păstrată de $56 \mathrm{~cm}$ și diametrul maxim $(\mathrm{Dm})$ de 18,5 cm (Figura 12/2). În cazul celei de-a doua amfore, pe înălțimea păstrată de $45 \mathrm{~cm}$ am putut măsura diametrul gurii $(\mathrm{Dg})$ de $6,5 \mathrm{~cm}$., respectiv diametrul maxim $(\mathrm{Dm})$ de $20,5 \mathrm{~cm}$. Se observă faptul că are dimensiuni asemănătoare cu cele anterioare.

Cele trei amfore fac parte din aceeaşi clasă denumită ,cu pastă fină” și gâtul lung, anume narrow-necked light-clay amphorae. Tipul respectiv, definit de D.B. Šelov şi S.Yu. Vnukov ${ }^{19}$, cuprinde şase variante (AE), considerate a fi etape evolutive ale aşa-numitei amfore "pseudo-cos"20.
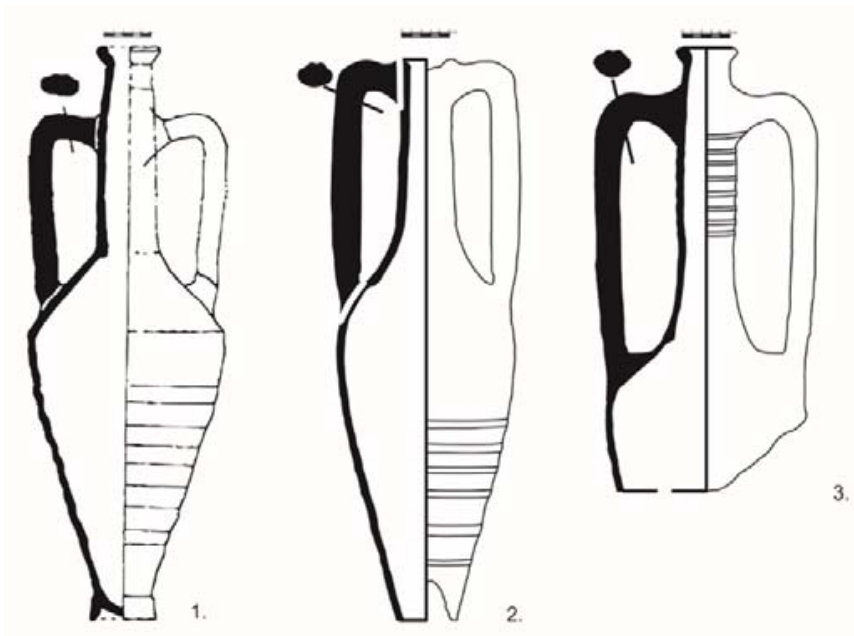

Figura 12. Amfore identificate în situl "Lta 14". 1) după Paraschiv 2006, 222, pl. 2/11; 2-3) desene Radu Stănescu.

Acest tip de amfore este atestat în toate siturile dobrogene între finele secolului I p.Chr. şi pe durata secolului următor, fiind unul dintre cele mai răspândite tipuri de amfore de la Dunărea de $\operatorname{Jos}^{21}$. Amfora este confecţionată din argilă de culoare deschisă de la portocaliu la galben, unele mai albicioase, conţinând mult nisip, placioclaste, ceramică pisată şi fragmente negre de piroxen şi mică. Corp piriform sau ovoidal terminat cu un picior scurt şi inel de susţinere, gât îngust care se lărgeşte spre partea inferioară, având o trecere lină spre umerii amforei, buză profilată, torţi profilate şi uşor arcuite, prinse în apropierea buzei şi la baza umărului amforei ${ }^{22}$. Originea acestor amfore pare a se situa în perioada

\footnotetext{
${ }^{17}$ Paraschiv 2006, 20, nota 114.

${ }^{18}$ Paraschiv 2006, p. 222 pl. 2/11.

19 Šelov 1986, 395-400; Vnukov 2004, 407-415; Vnukov 2016, 37.

${ }^{20}$ Abadie-Reynal 1999, 256; Opaiţ 2004, 31

${ }^{21}$ În literatura de specialitate din România, aceste amfore pot fi întâlnite în diferite alte clasificări: Rădulescu 2, Scorpan I, Opaiţ VI, Suceveanu LIV, Paraschiv 3 (Rădulescu 1976, 102 pl. I. 2,2a,3,3a; Scorpan 1977, 269; Opaiţ 1980, 301; Suceveanu 2000, tipul LIV; Paraschiv 2002, 170-171).

22 Dyczek 2001, 220
} 
elenistică, ele fiind produse cel mai probabil în Heracleea Pontică ${ }^{23}$. În secolele II-III p.Chr. a fost cel mai popular tip de amforă din zona sudică a Mării Negre ${ }^{24}$. Aceste amfore sunt foarte răspândite pe coastele Mării Negre, în special în Nord şi Vest ${ }^{25}$, fiind cel mai frecvent tip de amforă la Noviodunum ${ }^{26}$ sau din necropolele de la Histria ${ }^{27}$, Tomis $^{28}$ sau Galați̦ ${ }^{29}$. Cele trei amfore se încadrează în varianta B a acestui tip, putând fi datate în secolul II p.Chr. După cum menționam mai sus, descoperirea lor fiind foarte frecventă în necropole, situație care pare să fie întâlnită și în cazul pe care îl discutăm.

\section{ALTE SITURI ARHEOLOGICE DIN ZONA LUNCAVIȚA}

Situl numit convenţional „Lta 17” a fost descoperit în cadrul unor periegheze desfăşurate în ultimele decenii în marginea de sud-vest a satului Luncavița, în partea nordică a unui platou, aflat între Valea Moacii și Valea Joiței. Aici au fost descoperite fragmente de vase și de opaițe romane ${ }^{30}$.

Un alt sit, denumit „Lta 29”, se află pe o colină care are ca reper borna kilometrică $3+400$ a DJ Luncavița-Nifon. În zona Cetățuia, în timpul unei cercetări de suprafață din anul 1951, E. Comșa a semnalat identificarea unor fragmente ceramice atribuite perioadei romane. Ulterior au putut fi găsite trei gropi menajere conținând material databil în perioada romană $\breve{b}^{31}$.

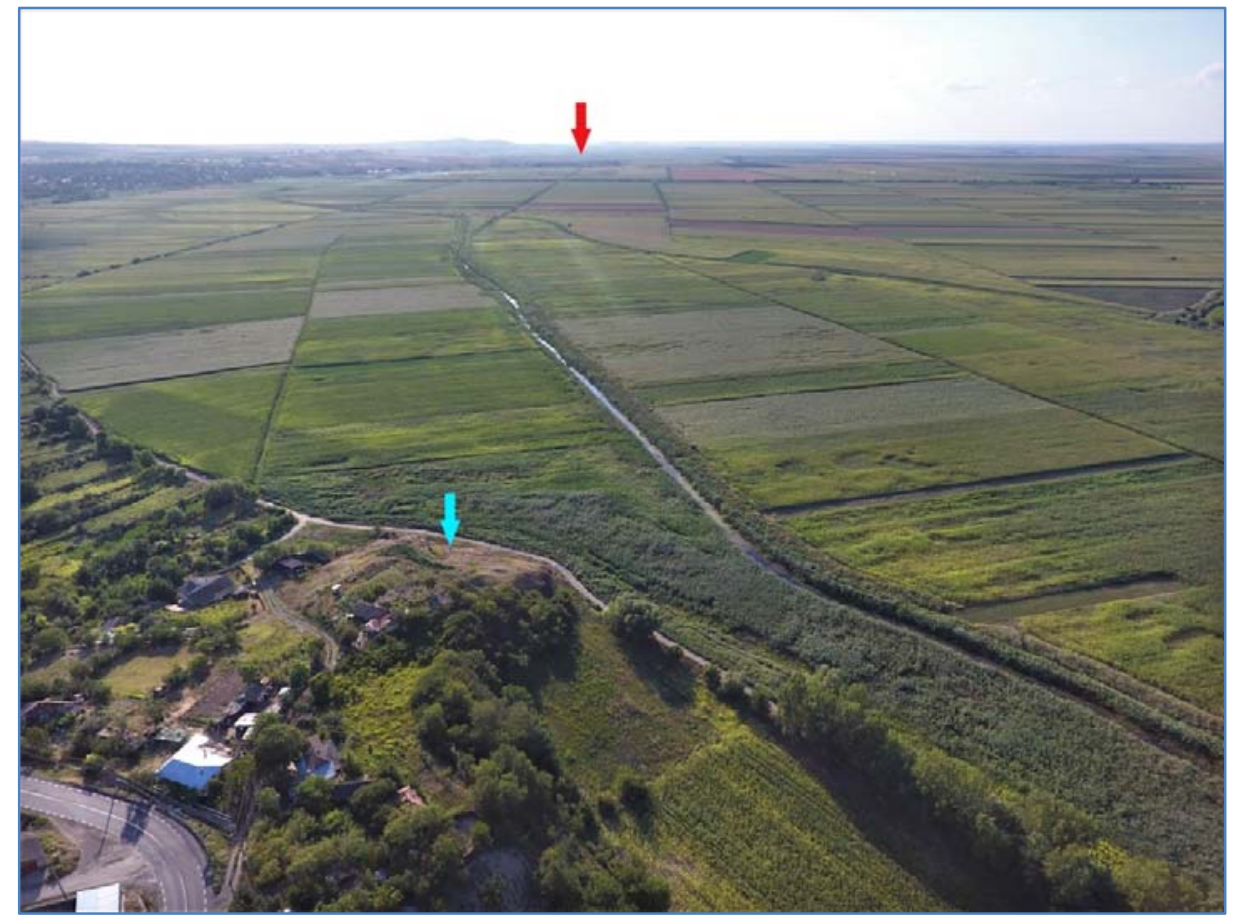

Figura 13.

Amplasarea

fortificațiilor de la

Luncavița,

Rachelu (prim

plan, săgeată

albastră) și

Luncavița, Milan

(plan îndepărtat, săgeată roșie).

Imagine

prelucrată dupăo fotografie aeriană realizată de Dan

Costea.

Fortificațiile de pe Dealul Milan și Rachelu, precum și situl Lta14 sunt amplasate pe terasa înaltă a Dunării, în imediata vecinătate a luncii inundabile a Dunării (Figura 13; revezi Figura 11), pe marginea

\footnotetext{
23 Šelov 1986, 400; Abadie-Reynal 1999, 256; Dyczek 2001, 215; Opaiţ 2004, 32, Vnukov 2004, 415. Producţia acestui tip de amfore la Heracleea se încadrează în intervalul crononogic cuprins între al doilea sfert al secolului I p.Chr. şi epoca romană târzie.

${ }^{24}$ Vnukov 2004, 415

${ }^{25}$ Abadie-Reynal 1999, 256; Dyczek 2001, 215

${ }^{26}$ Simion 1984, 84, 496 pl. XII.3,4.

${ }^{27}$ Alexandrescu 1966, 511 pl. 79.XVI 1-24; 531 pl. 99/XXX.6-8.

${ }^{28}$ Lungu, Chera 1986, 92, 108 pl. VI.62.

${ }^{29}$ Țentea, Cleșiu 2006, 45-46.

${ }^{30}$ Micu et al. 2012, Lta 17.

${ }^{31}$ Comșa 1953. Informații reluate și în Micu, Maille, 2002, 119; Micu et al. 2012, Lta 29.
} 
platoului. Acestă situație este o caracteristică a majorității fortificațiilor romane de pe frontiera dunăreană. Imaginea oferită de dispunerea celor cinci situri ne oferă o perspectivă mult mai relevantă a dimensiunii ocupării teritoriului în perioada Principatului și a modului în care funcționau instalațiile militare și rețelele rutiere.

\section{MULȚUMIRI}

Țin să le mulțumesc mai multor colegi pentru sprijinul acordat în vederea realizării acestui studiu. Lui Cristian Micu i se datorează informațiile de teren care actualizează informațiile referitoare la siturile romane delimitate și introduse în studiul istoric al Planului de Urbanism General, menționate în text (Lta 14, Lta 17, Lta 29). Radu Stănescu a realizat desenele amforelor din colecția Școlii Generale din Luncavița (fig. 16.2, 16.3). Dorel Paraschiv a făcut verificări ale inventarelor ICEM, aducându-ne clarificările necesare asupra provenienței amforelor. Vlad Călina a asigurat procesarea figurilor. Fotografiile din dronă au fost realizate de Daniel Costea.

Ovidiu Țentea (ovidiu.tenteaATgmail.com) este arheolog la Muzeul Naţional de Istorie a României

\section{BIBLIOGRAFIE}

Abadie-Reynal 1999 Abadie-Reynal, Catherine, Les amphores romaines en Mer Noire (1er - 4e s.), In: Y. Garlan (ed.), Production et commerce des amphores anciennes en Mer Noire, Aix-en-Provence, 1999, 255-264.

Alexandrescu 1966

Alexandrescu, P., Necropola tumulară. Săpături 1955-1961, În: Condurachi, E. (ed.), Histria II, București, Ed. Academiei R.S.R, 133-294.

Barnea 1986

Barnea, Al., La forteresse de Dinogetia à la lumière de dernières fouilles archéologiques, In: Studien zu den Militärgrenzen Roms III. Akten des 13. Internationalen Limeskongresses Aalen 1983, Stuttgart, 447-450.

Barnea 1996

Barnea, I., Luncaviţa,în Enciclopedia Arheologiei şi Istoriei Vechi Româneşti, vol. II (ed. C. Preda), București, Ed. Enciclopedică, 334.

Comșa 1953

Comşa, E., Contribuţie la harta arheologică a Dobrogei de Nord-Vest, SCIV IV, 3-4, 747-757.

Dyczek 2001

Florescu 1958

Dyczek, P., Roman Amphorae of the $1^{\text {st }}-3^{\text {rd }}$ Centuries AD Found on the Lower Danube. Typology, Wydawnictwa Uniwersytetu Warszawskiego, Warsaw.

Florescu, Gr., Locuintele, În: Gr. Florescu, R. Florescu, P. Diaconu, Capidava. Monografie arheologica, Bucuresști, 138-152.

Florescu 2004 Florescu, R., Bordeiul medio-bizantin de la Capidava și rolul său în viaţa familiilor de stratiotai, Sesiunea Zilele Antropologiei românești - Universul locuinței, Sibiu 2001, Istorie și tradiție în spațiul românesc, V, Sibiu, 2004, 253 259. - http://www.capidava.ro/publicatii.php\#2 
Băjenaru 2010

Gudea 2005

Haynes, Bogdan, Topoleanu 2007

Lahovari, Brătianu, Tocilescu 1901

Lungu, Chera 1986

Micu, Maille 2002

Micu et al. 2012

Opaiţ 1980

Paraschiv 2006

Poenaru-Bordea 1992-1993

Rădulescu 1976

Scorpan 1977

Šelov 1986

Simion 1984

Suceveanu 2000

Topoleanu, Bogdan, Haynes 2012
Băjenaru, C., Minor Fortifications in the Balkan-Danubian Area from Diocletian to Justinian, Cluj-Napoca, Mega Publishing House.

Gudea, N., Der untermoesische Donaulimes und die Verteidigung der moesischen Nord-und Westküste des Schwarzen Meeres. Limes et Litus Moesiae inferioris (86-275 n.Chr.), Sonderdruck aus Jahrbuch des RömischGermanischen Zentralmuseums Mainz 52, 2005, 319-566.

Haynes I., Bogdan, D., Topoleanu, F., Salsovia: A Roman Fort and Town on the Lower Danube. The Lower Danube in Antiquity (VI C BC - VI C AD), in: International Archaeological Conference Bulgaria-Tutrakan, 6.-7.10.2005 (ed. L.F. Vagalinski), Sofia, 131-140.

Lahovari, G.I., Brătianu, I.C., Tocilescu, G.G., Milanul, În: Marele dicţionar geografic al României alcătuit şi prelucrat după dicţionarele parţiale pe județe, IV, Bucureşti, 339.

Lungu, V., Chera, C., Contribuţii la cunoaşterea complexelor funerare de incineraţie cu "rug-busta" de epocă elenistică şi romană de la Tomis, Pontica XIX, 89-111.

Micu, C., Maille, M., Rechérches archeologiques dans le cadre de l'etablissement-tell de Luncaviţa, (dep. de Tulcea), Studii de Preistorie I, 115129.

Micu, C. , Ailincăi, S., Mihail, Fl., Stănică, A., Panait, V., Costea, Iuliana, Dima, Ligia, Mocanu, M., Iacob, Mihaela, Paraschiv, D., Studiu istoric şi arheologic comuna Luncavița, Tulcea.

Opaiţ, A., Consideraţii preliminare asupra amforelor romane şi romanobizantine din Dobrogea, Peuce VIII, 291-327.

Paraschiv, D., Amfore romane și romano-bizantine în zona Dunării de Jos (sec. I-VII p.Chr.), Iași, Editura Fundaţiei Axis.

Poenaru-Bordea, Gh., Ocheşeanu, R., Un tezaur de denari romani din secolul I p.Chr. de la Rechelu şi câteva descoperiri monetare izolate din comuna Luncaviţa, jud. Tulcea (Un trésor de dénars romains du Ier siecle apres J. C. de Rachelu et quelques découvertes monétaires isolées de la commune de Luncaviţa), BSNR, 1992-1993 [1996], 86-87, nr. 140-141, 77-94.

Rădulescu, A., Amfore romane şi romano-bizantine din Scythia Minor, Pontica IX, 1976, 99-114.

Scorpan, C., Contributions à la connaissance de certains types céramiques romano-byzantins (IVe-VIIe siècles) dans l'espace istro-pontique, Dacia N.S. XXI, 269-297.

Šelov, D. B., Les amphores d'argile claire des prèmiers siècles de notre ère en Mer Noire, In: J.-Y. Empereur, Y. Garlan (éd.), Recherches sur les amphores grecques. Actes du colloque international (Athènes, 10-12 Septembre 1984), Bulletin de Correspondance Hellénique. Supplément 13, Athènes, 395-400.

Simion, G., Descoperiri noi în necopola de la Noviodunum. Raport preliminar, Peuce IX, 1984, 75-96, 481-502.

Suceveanu, Al., Histria X, Ceramica romană din secolele I - III p.Chr, Bucureşti, Editura CIMEC TIR L 35 -Tabula Imperii Romani: L 35, Romula-DurostorumTomis, Bucarest, Editura Academiei Republicii Socialiste România.

Topoleanu, F., Bogdan, D., Haynes, I., Salsovia: chronological landmarks, Peuce, S.N. X, 2012, 101-144. 
Tocilescu 1882

Tocilescu 1898

Țentea, Cleșiu 2006

Țentea, Oltean 2009

Țentea 2015

Vnukov 2004

Vnukov 2016

Zahariade, Gudea 1997

Zahariade 1999

Zahariade 1988
Gr G. Tocilescu, Monumente epigrafice şi sculpturale din Dobrogea, Revista pentru istorie, arheologie si filologie I, 97 - 132.

Tocilescu, Gr. G. mss. rom. 513 [Biblioteca Academiei Române], 1898 [5132] mss. 100-101.

Țentea, O., Cleșiu, S., Fortificaţia şi necropola romană de la Galaţi, Cart. „Dunărea”. Raport arheologic, Cercetări Arheologice 13, 39-88.

Țentea, O., Oltean, Ioana, A., The Lower Danube Roman Limes at Galaţi (Romania). Recent results from excavation and aerial photographic interpretation, In: Limes XX: Estudios sobre la Frontera Romana, Roman Frontier Studies, vol. III, Anejos de Gladius 13, León, Spain, September 2006, eds. A. Morillo, N. Hanel, E. Martín, Madrid, Polifemo, 2009, 1515-1524.

Țentea, O., Closing a gap. A roman fort rediscovered, in Limes XXII. Proceedings of the XXIIth International Congress of Roman Frontier Studies, Ruse, Bulgaria, September 2012 (eds. L. Vagalinski, N. Sharankov) (= Bulletin of the National Archaeological Institute XLII, 2015), Sofia 2015, 269-276.

Vnukov, S. Y., Pan-roman amphora types produced in the Black Sea Region, In: J. Eiring, J. Lund (eds.), Transport Amphorae and Trade in the Eastern Mediterranean, Acts of the International Colloquium at the Danish Institute at Athens, September 26-29, 2002 (Monographs of the Danish Institute at Athens 5), Athens, 407-415.

Vnukov, S. Y., Еще раз о типологии, эволюции и хронологии светлоглиняных (позднегераклейских) узкогорлых амфор (On the typology, evolution and chronology of light- clay (late Heraclean) narrow-necked amphorae), Российская археология (Rossijskaja Arheologija) II, 36-47.

Zahariade, M., Gudea, N., The Fortifications of Lower Moesia (AD 86-275), Amsterdam, Hakkert.

Zahariade, M., The Roman Frontier in Scythia Minor (1980-1995). Proceedings of the XVIIth International Congress of Roman Frontier Studies, Zalău 1997, Zalău 1999, Publishing House Porolissum, 199-213.

Zahariade, M., Moesia Secunda, Scythia și Notitia Dignitatum, Editura Academiei Republicii Socialiste România București.

\section{ILLUSTRATIONS}

Figure 1. Map of the Roman provinces situated in the Lower Danube region during the Principate (left) and detail (right).

Figure 2. Luncavitga, spot Milan, plan of the fort (after Tocilescu 1989, 100-101).

Figure 3. Luncavitga-Milan, orthophoto (left) and photointerpretation (right), both following Tentea 2015, 272, fig. 6 a.

Figure 4. Plan published by G. Tocilescu (1989, 100-101) for Luncaviţa fort overlaid a digital terrain model (left), orthophoto (middle), and a hillshade digital model highlighting the slopes.

Figures 5-6. Oblique photos on Luncaviţa-Milan (Dan Costea 2018).

Figure 7. Vertical photos, Luncaviţa-Milan (Dan Costea 2018).

Figure 8. Interpreting existing evidence for the inner buildings of the fort (black) and the modern 
tranches (white, red), on the same image set as in the Figure 4.

Figure 9. Sketch of the archaeological site from Noviodunum (detail), showing the trenches of the First World War (red lines). Ottoman fort (tabia) on left and some towers of the Late Roman fort (right).

Figure 10. Outline of the Salsovia stronghold (black) with some modern trenches (red). Hillshaded terrain model overlapped by the restituted plan, after Topoleanu, Bogdan, Haynes 2012, 110, fig. 20.

Figure 11. The Roman archaeological sites around Luncaviţa - elevation model.

Figure 12. Amphorae found on 'Lta14' site. 1) following Paraschiv 2006, 222, pl. 2/11; 2-3) drawing made by Radu Stănescu.

Figure 13. Location of the forts from Luncaviţa Rachelu (foreground, blue) and Luncaviţa-Milan (background, red). Snapshot by Dan Costea, heading west. 